\title{
The role of adult noctuid moths (Lepidoptera: Noctuidae) and their food plants in a nocturnal pollen-transport network on a Mediterranean island
}

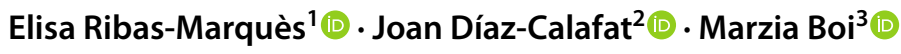

Received: 4 November 2021 / Accepted: 26 January 2022 / Published online: 7 February 2022

(c) The Author(s) 2022

\begin{abstract}
Noctuidae belong to one of the largest families of night-flying Lepidoptera. However, despite being among the most common nocturnal flower-visitors, they have seldom been included in pollination networks. Similarly, the current knowledge on food plants used by adults is rather scarce. In this article, we build the first moth-plant pollen transfer network in the Balearic archipelago. We aim to increase the knowledge of which plants are used as food resources by adult Noctuidae, assess how specific or generalist nocturnal pollinators and their food plants are and establish the first baseline information on adult Noctuidae-plant interactions on the archipelago and the Mediterranean. 20.7\% of the adult Noctuidae in our samplings carried pollen and were therefore potentially involved in nocturnal pollination. The family Ericaceae, and especially Arbutus unedo, was a key food resource for our moth community, with $46 \%$ of the total recorded interactions belonging to this plant. Overall, both plants and moths in our system behaved in a generalist way. Niche overlap was larger in moths than in plants, suggesting that the functional role that moth species take in our system is more redundant than that taken by plants. Robustness values suggest that the network functionality would not collapse despite the extinction of a few species.

Implications for insect conservation Detecting flower preferences and the role of nocturnal insects on pollination will allow understanding of ecosystem functionality and will be crucial for conservation of both moths and organisms that depend on them.
\end{abstract}

Keywords Moths $\cdot$ Nocturnal pollination $\cdot$ Arbutus unedo $\cdot$ Conservation $\cdot$ Pollen network $\cdot$ Balearic Islands

\section{Introduction}

Animal-mediated pollination is an essential process in all ecosystems in which plants depend on animal pollen transfer to reproduce (González-Varo et al. 2013). Pollinators play, therefore, a critical role for biodiversity maintenance and ecosystem functioning whilst at the same time providing an important ecosystem service for the production of many food crops (Ollerton et al. 2011). Among all pollinators, insects

Joan Díaz-Calafat

joandiazcalafat@gmail.com

1 Independent Researcher, Camí de Gènova 33, 3A, 07014 Palma, Mallorca, Balearic Islands, Spain

2 Southern Swedish Forest Research Centre, Swedish University of Agricultural Sciences, 23053 Alnarp, Sweden

3 Centro UNED Illes Balears, Universidad Nacional de Educación a Distancia, Palma, Spain are central to pollination, representing the vast majority of animal-plant interactions (Ollerton et al. 2011). However, despite bees and bumblebees having been well documented as effective pollinators, other flower visitors such as flies, beetles, butterflies and moths appear to have been overlooked in comparison (Rader et al. 2016).

The majority of Lepidoptera visit flowers in order to take profit from their nectar (Krenn 2010). This insect order is very diverse, with approximately 165,000 species (Kristensen et al. 2007; Regier et al. 2009), which is estimated to be close to $10 \%$ of insect species worldwide (Willmer 2011). However, research regarding plantLepidoptera interactions has mostly focused on butterflies, despite moths representing approximately $90 \%$ of Lepidoptera species (Ricketts et al. 2001). Consequently, research has mainly considered diurnal pollination networks and has neglected nocturnal pollination until rather recently. Nevertheless, nocturnal pollination research does exist, albeit still fragmentary and unevenly across moth 
and other insect and non-insect taxa. For instance, whilst extensive research has been done in tropical areas with nocturnal bees (e.g. Cordeiro et al. 2017) and bats (e.g. Bumrungsri et al. 2008), these matters have been less intensively studied in temperate zones of the Old World, mainly involving moths (e.g. Banza et al. 2015) and flies (e.g. Orford et al. 2015), among others. See Macgregor and Scott-Brown, (2020) for a general world-wide synthesis.

Moths have been shown to be of general importance to pollination in a variety of ecosystems across all continents except Antarctica (Macgregor et al. 2015). In fact, some moths have been proven capable of carrying pollen further than other insects, providing genetic benefits to plant populations (i.e. greater interpopulation gene flow) (Herrera 1987; Macgregor et al. 2015, 2019). Nevertheless, there are still considerable knowledge gaps about their role as pollinators (Hahn and Brühl 2016; Van Zandt et al. 2020), and they have seldom been included in pollination networks until recently (Banza et al. 2015; Devoto et al. 2011; Macgregor and ScottBrown (2020; Walton et al. 2020). Within this insect group, Noctuidae are among the largest families of night-flying Lepidoptera (Mitter et al. 1993) and, together with Sphingidae, are among the most common nocturnal flower-visitors (Hahn and Brühl 2016; Macgregor et al. 2015; Winfree et al. 2011).

Most nocturnal pollination interactions can be attributed to Noctuidae species (Hahn and Brühl 2016). Therefore, given the importance of this family, we decided to focus on this group. We analysed the structure of a nocturnal plantvisitor network on Mallorca, the major island of the Balearic archipelago (Western Mediterranean), using pollen-based methods through traditional light microscopy. With this method, we expected to (1) increase the knowledge of which plants are used as feeding resources by adult Noctuidae, (2) assess how specific or generalist nocturnal pollinators and their food plants were in terms of interactions and (3) establish the first baseline information on adult Noctuidae-plant interactions on the Balearic archipelago, this being the first article addressing such relationships in the Mediterranean basin. To fully understand how pollination works in a given ecosystem, interactions that occur in the dark should not be disregarded. Moreover, as terrestrial ecosystems are undergoing several threats that could lead to an important decline of both animal and plant biodiversity, spatial range shifts or changes in activity and phenology, crucial changes in plantpollinator interactions will probably occur (Gill et al. 2016; Biesmeijer et al. 2006; Potts et al. 2010; Macgregor et al. 2015). In the face of this situation, it is imperative to understand the functional role that nocturnal insects play as pollinators, and to see whether such roles will be functionally replaced by other pollinator species that manage to adapt or arrive with climate change. Understanding how animals and plants interact, for instance, building ecological networks and studying how they are structured, is among the most important aims of ecological research (Banza et al. 2015).

\section{Material and methods}

\section{Study sites and moth sampling}

Located in the Western Mediterranean (Fig. 1A), the Balearic Islands $\left(39^{\circ} 37^{\prime} 00^{\prime \prime} \mathrm{N}, 2^{\circ} 59^{\prime} 00^{\prime \prime} \mathrm{E}\right)$ are subject to a climate characterized by rain seasonality and its inconsistency, with relatively mild winters and very warm dry summers (Garau and Gelabert 2009). Despite being considered a biodiversity hotspot, no comprehensive work on the moth diversity of the Balearic Islands has been published so far. However, all data gathered until now suggest an approximate minimum number of 214 Noctuidae species in the Balearic Islands (M. R. Honey pers. comm.).

Moth catching took place in the south-east of Mallorca, the largest island of the Balearic archipelago (Fig. 1B). In order to obtain a more complete view on moth-plant interactions on the island, samplings were carried out in two different sites similar in terms of vegetation composition but different in elevation: the Natural Park of Mondragó (Santanyí, $39^{\circ} 21^{\prime} 22.8^{\prime \prime} \mathrm{N}, 3^{\circ} 11^{\prime} 24.9^{\prime \prime} \mathrm{E}, 23$ m.a.s.1.) and the Puig de Sant Salvador (Felanitx, 39 27' 21.1" N, 3 11' 10.6" E, 467 m.a.s.1.). These sites are within moth flying-distance (ca. $10 \mathrm{~km})$ and therefore cannot be considered independent (Betzholtz and Franzen 2011). Different elevation and cooler temperatures associated with increasing altitude may affect both plant and Lepidoptera phenology and distribution (Bell et al. 2019). Therefore, increasing our sampling area through the inclusion of both sites provides us with a broader range of opportunities to detect plant-moth interactions that could otherwise have been overlooked. Both locations are dominated by a tree cover of Quercus and Pinus species (mainly Quercus ilex L. and Pinus halepensis Mill.), a shrub cover of representative Mediterranean species (e.g. Arbutus unedo L. 1753, Erica multiflora L. 1753, Cistus spp., etc.) and crop fields in the near surroundings (Leiva and Moris 2001; Siquier i Vigrós and Salom 2003).

Moth sampling was restricted to species exclusively belonging to the family Noctuidae sensu lato. Samplings were conducted using a Robinson light trap $(125 \mathrm{~W})$. The trap was placed on top of a white blanket so moths close to the light source but not inside the trap would be visible. In order to avoid damaging the specimens that were attracted to the light, several egg boxes were put inside the light trap (Jonason et al. 2014). Some egg boxes were also placed on top of the white blanket (Fig. 1C). In the end of each survey, all moths inside the trap and on the blanket were collected. The trap was always placed in the vicinity of buildings for power source, yet our study areas were rather far from urban 


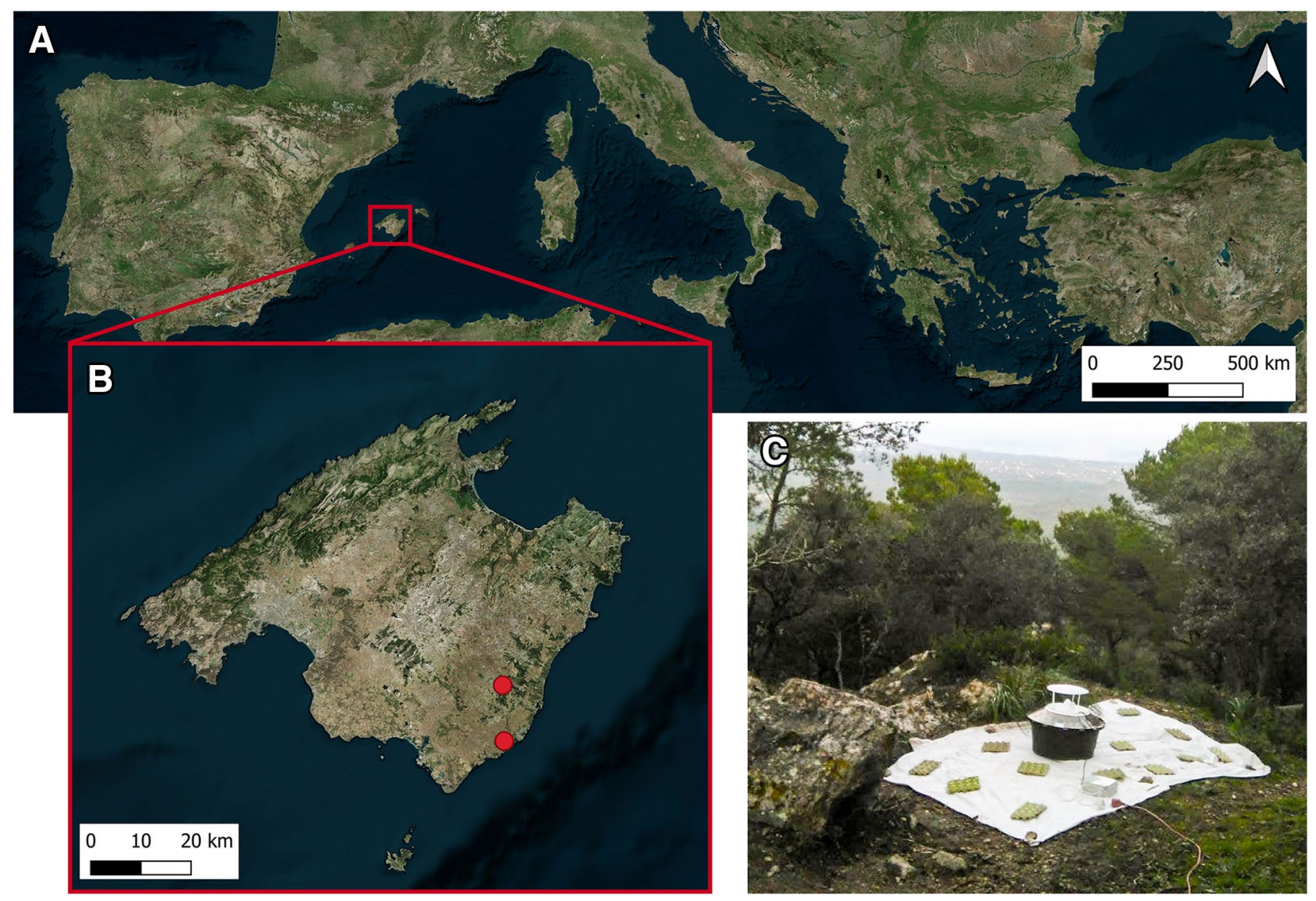

Fig. 1 A Location of our study region (island of Mallorca) within the Mediterranean Sea. B Location of our study sites within the island of Mallorca. C Overview of the light-trap setup used for this study

areas. The trap was set before sunset and collected right after sunrise. Sampling time per night naturally fluctuated depending on night-time length at different times of the year. Two samplings per month and site were carried out as a representative snapshot of three different seasons: autumn (in November 2017), winter (in January 2018) and spring (in April 2018). Both sites were sampled in consecutive days and revisited every second week within each month. Moths were identified to the lowest possible taxonomic level [using Bachelard (2008) and Waring and Townsend (2017)] and were stored individually frozen for future examination.

\section{Examination of pollen attached to moths}

All moths collected throughout the three sampling seasons were inspected for pollen presence. Pollen attached to these moths was examined under a stereo microscope (Leica ZOOM 200, magnification $10.5 \times-45 \times$ ). This examination was restricted to the moths' proboscis (Fig. 2A, B) since it is usually kept coiled when resting and uncurled when feeding (Krenn 1990; Davies and Butler 2008). This prevents possible cross-contamination when moths that have fallen together into the light trap overnight are in potential contact with each other (Macgregor et al. 2017). Moreover, to further reduce this risk, only those individuals with more than five attached pollen grains were considered as flower visitors (as suggested by Devoto et al. (2011)). Once all moths that carried pollen were selected, they were pooled and a representative random subset was selected for analyses (see Supplementary Material 1), due to budget and time limitations. All moths with attached orchid pollinia were included in the network.

\section{Pollen preparation and identification}

Pollen analysis was performed using traditional microscopy techniques, following the protocol of Soldevilla et al. (2007). We collected pollen grains with a dissecting needle and individually transferred them to microscope slides. A small amount of fuchsin glycerine jelly was placed above the pollen sample and was later covered with a coverslip (Fig. 2C). In order to distribute the glycerine jelly uniformly and make the preparation permanent, the medium was melted under low heat and then sealed with transparent nail polish. A total 

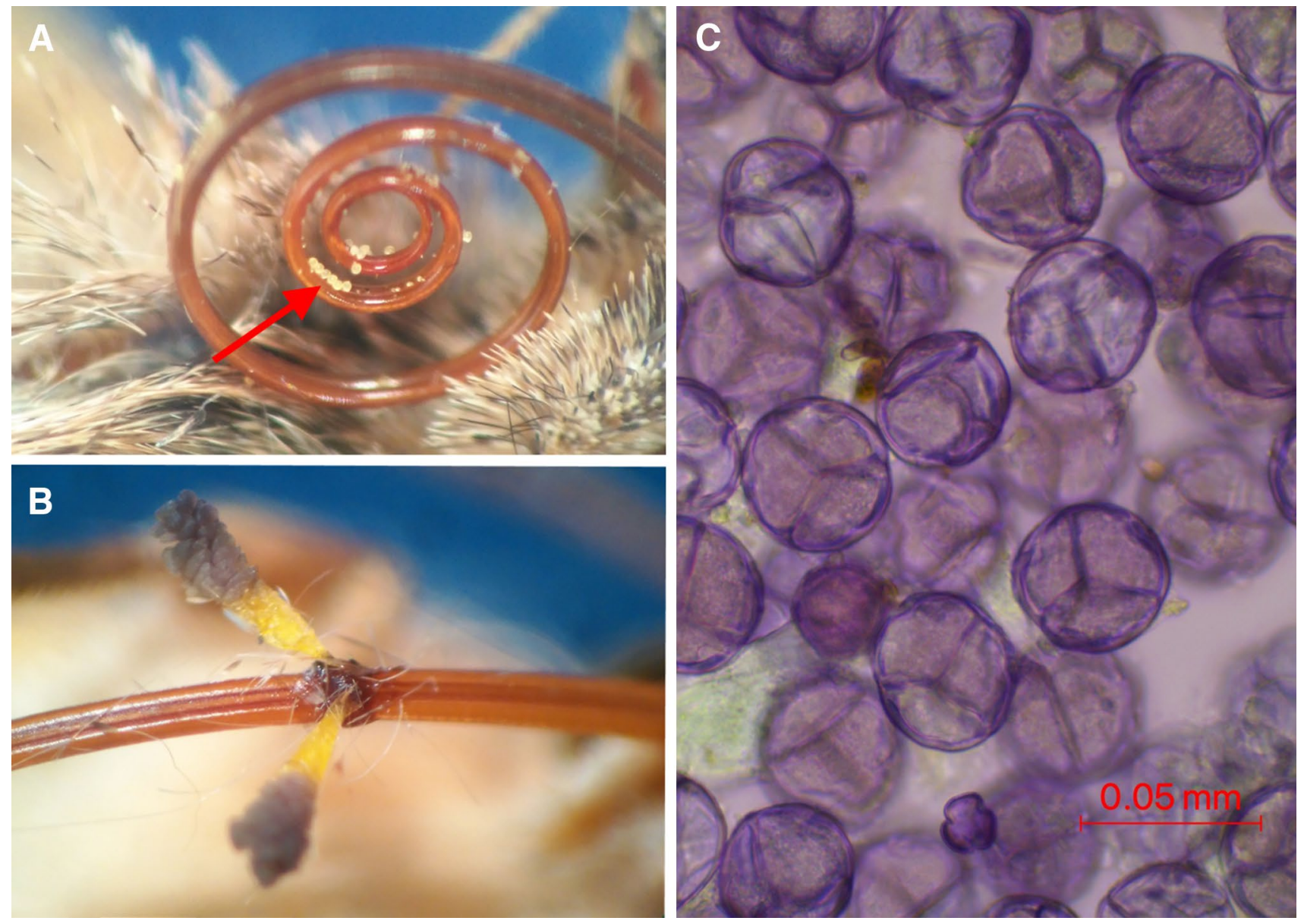

Fig. 2 A Coiled proboscis of a moth with pollen attached to it. B Pollinium of Anacamptis pyramidalis attached to the proboscis of Heliothis peltigera. $\mathbf{C}$ Microscopic slide preparation of Arbutus unedo pollen after fuchsine tinction

of 100 pollen slides were prepared and checked for pollen identification. Microscope slides were observed and identified with light microscopy at $1000 \times$ magnification with an Olympus microscope (model BX41). Different literature was consulted (Valdés et al. 1987; Reille 1992, 1995, 1998; Hesse et al. 2009) for pollen identification. Due to the intrinsic difficulty of identifying plant pollen morphologically (Richardson et al. 2015), some pollen samples were only identified at genus, family level or at pollen morphologicalgroup. These categories were the ones used in the plantmoth network analyses.

\section{Plant-moth network analyses}

Bipartite plots were built with the 'bipartite' $\mathrm{R}$ package (Dormann et al. 2008) in R 4.1.1 (R Core Team 2021). Network metrics were calculated with the same package, both at node level (i.e. at species level for both plants and pollinators) and at the network scale.

At the full network level, the following metrics were calculated: mean number of species, mean number of links, mean number of shared partners, partner diversity (using Shannon's index), niche overlap (for both plants and moths), extinction slope (for both plants and moths), robustness (for both plants and moths), connectance, weighted connectance, web asymmetry, network specialisation $\left(\mathrm{H}_{2}^{\prime}\right)$ and linkage density (i.e. network complexity). The following metrics were calculated at the node level: degree, species strength, interaction asymmetry strength (i.e. "species push-pull" in Dormann et al. (2008), calculated as in Vázquez et al. (2007)) and species specificity. Details on the equations and calculations of species-level metrics can be found in Dormann (2011), and those involving the full network in Dormann et al. (2009).

\section{Results}

In total, moths were sampled during $150 \mathrm{~h}$ and $13 \mathrm{~min}$; with the longest nights in January 2018 ( $c a .14-15 \mathrm{~h}$ ) and the shortest nights in April 2018 (ca. 10-11 h). In total, 952 moths were collected, corresponding to 46 species. Of all 
the specimens collected, $20.7 \%$ had at least 5 pollen grains attached to their proboscis. This involved 23 out of these 46 species carrying pollen. Only the pollen within a subset of these moths was identified (see Supplementary Material 1). Sixteen different plant families were identified. After taking into consideration all the interactions inferred from the pollen identification, 23 moth and 27 plant taxa remained in three different network compartments (Fig. 3). For a complete record of which moth species interacted with which plant species refer to Supplementary Material 2.

Not all plants could be identified to species level through pollen morphology examination due to the intrinsic limitations of such a method (Richardson et al. 2015), and therefore some were left at genus or family level. In some cases, pollen was classified in "types" according to morphology (e.g. Asteraceae Bellis-like or Fabaceae Genista-like, referring to the pollen morphological group). There were two Ericaceae records that could not be identified to the species level, but based on the local flora, they should belong to either Erica multiflora or Arbutus unedo. However, such pollen samples did not allow the separation between these two taxa. As it would be inconvenient to add them to the network as Ericaceae (i.e. creating a new species independent from Arbutus unedo and Erica multiflora), these records were omitted from the analyses. We expect this not to have a big effect
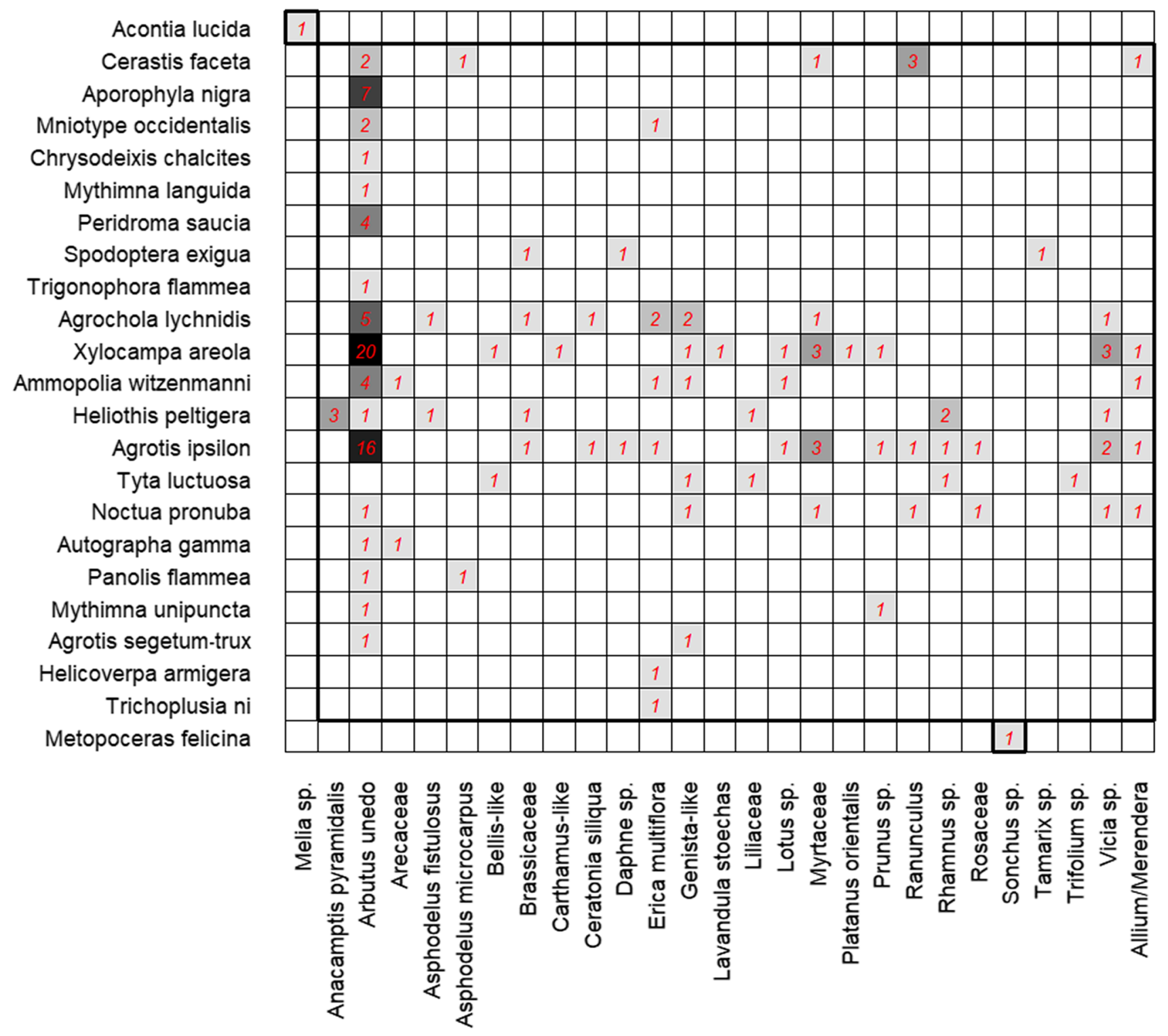

Fig. 3 Visualisation of the adjacency matrix of the moth-plant interactions recorded in this study. The darker a cell is represented; the more interactions have been recorded. The number of interactions can be found in the numbers within each cell. White cells with no number represent no interactions. Three compartments can be seen in the network (interactions within each bold frame) 
on our analyses, since the moths carrying such pollen also visited Arbutus unedo.

The moths Agrotis segetum (Denis \& Schiffermüller, 1775) and Agrotis trux (Hübner, 1824) were considered a complex of species since specimens from these species were too damaged to tell apart from each other. Hence, hereby they are referred as Agrotis segetum-trux.

Among the moths included in the network, Xylocampa areola (Esper, 1789) and Agrotis ipsilon (Hufnagel, 1766) were the most common catches transporting pollen (51 and 57 individuals, respectively). Among the plants, Arbutus unedo was by far the most recorded species (found in 69 pollen samples out of 150).

\section{Metrics at the network level}

The weighed mean number of links was 9.80 per plant taxa and 7.84 per moth species, with 0.70 and 0.88 of mean shared partners for plants and moths respectively. When taking into account partner diversity through the mean Shannon diversity index of the number of interactions for the species of each level (i.e. plants and moths), diversity diverged only slightly between both levels (1.61 for plants and 1.43 for moths). The web asymmetry index scored -0.08 , since there are more plant taxa than moth species in our network. Connectance (realised proportion of possible links) was 0.14 when considering our network binary, and 0.11 when weighting the interactions by their frequency. Linkage density (i.e. network complexity) was 5.41 .

Despite some moth species visiting only one or a few plant taxa in our network [e.g. Aporophyla nigra (Haworth, 1809) and Peridroma saucia (Hübner, 1808) only visiting Arbutus unedo or Anacamptis pyramidalis (L.) Rich. (1817) only being visited by Heliothis peltigera (Denis \& Schiffermüller, 1775)], network specialisation (understood as $\mathrm{H}_{2}^{\prime}$ ) was 0.21 , pointing out that the components in our network were not behaving in a specialised way and that the overall nature of the interactions was rather generalist at the network level.

When it comes to the similarity in the interaction patterns between species, moths had a higher niche overlap $(0.34)$ than plants $(0.20)$. These values reach 1 when niche overlap is absolute, and 0 when species do not share their ecological niche. Extinction slope was slightly higher for moths (2.27) than for plants (2.16), despite robustness to such extinction slopes being similar for both moths and plants (moths $=0.69$; plants $=0.68$ ). Robustness at each level is calculated based on the extinction slope at the opposite level. See these values compared to those obtained in other research in Table 2.

\section{Metrics at the species level}

Species relevance across all their partners was quantified as the sum of dependencies of each species. Within plants, the most relevant species was Arbutus unedo, with a "species strength" score of 10.07, followed by Erica multiflora and Genista-like Fabaceae (see Table 1A). Within moths, Xylocampa areola had the highest score, followed by Agrotis ipsilon and Heliothis peltigera (see Table 1B).

When quantifying the mismatch between a focal species' effect on its interaction partners and their reciprocal effect on the focal species, only Arbutus unedo, Erica multiflora and Genista-like taxa were strongly affecting the moth community by being very generalist, according to the formula of Vázquez et al. (2007). Melia sp. and Sonchus sp. obtained a neutral score (i.e. a 0 ), since they were only interacting with one species. Values close or equal to 0 reflect little to no interaction asymmetry strength. The rest of the plant taxa obtained a negative score, meaning that they interacted with fewer moths and therefore were more specific than Arbutus unedo, Erica multiflora and Genista-like taxa (Table 1A). Regarding moths, the ones that affected the plant community the most through their interactions were: Xylocampa areola, Tyta luctuosa (Denis \& Schiffermüller, 1775), Heliothis peltigera, Spodoptera exigua (Hübner, 1808), Agrotis ipsilon, Agrochola lychnidis (Denis \& Schiffermüller, 1775), Cerastis faceta (Treitschke, 1835), Ammopolia witzenmanni (Standfuss, 1890) and Noctua pronuba (Linnaeus, 1758). On the other hand, Autographa gamma (Linnaeus, 1758), Panolis flammea (Denis \& Schiffermüller, 1775), Mythimna unipuncta (Haworth, 1809), Mniotype occidentalis Yela, Fibiger, Ronkay \& Zilli, 2010, Agrotis segetum-trux, Helicoverpa armigera (Hübner, 1808), Trichoplusia ni (Hübner, 1803), Aporophyla nigra, Peridroma saucia, Chrysodeixis chalcites (Esper, 1789), Mythimna languida (Walker, 1858) and Trigonophora flammea (Esper, 1785) were strongly affected by the plant level (i.e. Arbutus unedo, Erica multiflora and Genista-like taxa) more than they were affecting the totality of plant taxa themselves, as their interactions were more specific. This metric is highly correlated with species strength but quantifies net balance rather than the average effect (Dormann 2011). Find this metric on Table $1 \mathrm{~A}$ and $\mathrm{B}$.

To assess plant and moth specificity in our network, we computed the species specificity index for each plant and moth species. This value reaches 1 when the species is completely specific and 0 when it is generalist. The most specific moths with more than one interaction record in our dataset were Peridroma saucia and Aporophyla nigra, that only visited Arbutus unedo, followed by Mniotype occidentalis, that only visited Arbutus unedo and Erica multiflora (both Ericaceae). The most generalist moth species were Noctua pronuba and Heliothis peltigera, visiting 7 different 
Table 1 Metrics calculated at the species level for the plant taxa (A) and moth species (B) within the network

\begin{tabular}{|c|c|c|c|c|}
\hline \multicolumn{5}{|l|}{ A } \\
\hline & Degree & Species strength & $\begin{array}{l}\text { Interaction asym- } \\
\text { metry }\end{array}$ & $\begin{array}{l}\text { Species } \\
\text { specificity } \\
\text { index }\end{array}$ \\
\hline Arbutus unedo & 17 & 10.07 & 0.53 & 0.35 \\
\hline Erica multiflora & 6 & 2.62 & 0.27 & 0.38 \\
\hline Genista-like & 6 & 1.13 & 0.02 & 0.38 \\
\hline Melia sp. & 1 & 1.00 & 0.00 & 1.00 \\
\hline Sonchus sp. & 1 & 1.00 & 0.00 & 1.00 \\
\hline Myrtaceae & 5 & 0.52 & -0.10 & 0.47 \\
\hline Vicia sp. & 5 & 0.47 & -0.11 & 0.46 \\
\hline Allium/Merendera & 5 & 0.44 & -0.11 & 0.40 \\
\hline Brassicaceae & 4 & 0.54 & -0.12 & 0.46 \\
\hline Prunus sp. & 3 & 0.56 & -0.15 & 0.55 \\
\hline Ranunculus sp. & 3 & 0.55 & -0.15 & 0.64 \\
\hline Asphodelus microcarpus & 2 & 0.63 & -0.19 & 0.69 \\
\hline Rhamnus sp. & 3 & 0.43 & -0.19 & 0.59 \\
\hline Arecaceae & 2 & 0.61 & -0.19 & 0.69 \\
\hline Lotus sp. & 3 & 0.17 & -0.28 & 0.55 \\
\hline Daphne sp. & 2 & 0.37 & -0.32 & 0.69 \\
\hline Liliaceae & 2 & 0.30 & -0.35 & 0.69 \\
\hline Bellis-like & 2 & 0.23 & -0.39 & 0.69 \\
\hline Rosaceae & 2 & 0.18 & -0.41 & 0.69 \\
\hline Asphodelus fistulosus & 2 & 0.17 & -0.41 & 0.69 \\
\hline Ceratonia siliqua & 2 & 0.10 & -0.45 & 0.69 \\
\hline Tamarix sp. & 1 & 0.33 & -0.67 & 1.00 \\
\hline Anacamptis pyramidalis & 1 & 0.30 & -0.70 & 1.00 \\
\hline Trifolium sp. & 1 & 0.20 & -0.80 & 1.00 \\
\hline Carthamus-like & 1 & 0.03 & -0.97 & 1.00 \\
\hline Lavandula stoechas & 1 & 0.03 & -0.97 & 1.00 \\
\hline Platanus orientalis & 1 & 0.03 & -0.97 & 1.00 \\
\hline \multicolumn{5}{|l|}{$\bar{B}$} \\
\hline & Degree & Species strength & $\begin{array}{l}\text { Interaction asym- } \\
\text { metry }\end{array}$ & $\begin{array}{l}\text { Species } \\
\text { specificity } \\
\text { index }\end{array}$ \\
\hline Xylocampa areola & 11 & 5.51 & 0.41 & 0.59 \\
\hline Tyta luctuosa & 5 & 2.39 & 0.28 & 0.41 \\
\hline Heliothis peltigera & 7 & 2.89 & 0.27 & 0.39 \\
\hline Spodoptera exigua & 3 & 1.75 & 0.25 & 0.55 \\
\hline Agrotis ipsilon & 13 & 4.02 & 0.23 & 0.51 \\
\hline Agrochola lychnidis & 8 & 2.13 & 0.14 & 0.40 \\
\hline Cerastis faceta & 5 & 1.44 & 0.09 & 0.47 \\
\hline Ammopolia witzenmanni & 6 & 1.38 & 0.06 & 0.48 \\
\hline Noctua pronuba & 7 & 1.29 & 0.04 & 0.33 \\
\hline Acontia lucida & 1 & 1.00 & 0.00 & 1.00 \\
\hline Metopoceras felicina & 1 & 1.00 & 0.00 & 1.00 \\
\hline Autographa gamma & 2 & 0.51 & -0.24 & 0.69 \\
\hline Panolis flammea & 2 & 0.51 & -0.24 & 0.69 \\
\hline Mythimna unipuncta & 2 & 0.35 & -0.33 & 0.69 \\
\hline Mniotype occidentalis & 2 & 0.17 & -0.41 & 0.73 \\
\hline Agrotis segetum-trux & 2 & 0.16 & -0.42 & 0.69 \\
\hline
\end{tabular}


Table 1 (continued)

\begin{tabular}{lllll}
\hline B & & & & \\
\hline & Degree & Species strength & $\begin{array}{l}\text { Interaction asym- } \\
\text { metry }\end{array}$ & $\begin{array}{l}\text { Species } \\
\text { specificity } \\
\text { index }\end{array}$ \\
\hline Helicoverpa armigera & 1 & 0.14 & -0.86 & 1.00 \\
Trichoplusia $n i$ & 1 & 0.14 & -0.86 & 1.00 \\
Aporophyla nigra & 1 & 0.10 & -0.90 & 1.00 \\
Peridroma saucia & 1 & 0.06 & -0.94 & 1.00 \\
Chrysodeixis chalcites & 1 & 0.01 & -0.99 & 1.00 \\
Mythimna languida & 1 & 0.01 & -0.99 & 1.00 \\
Trigonophora flammea & 1 & 0.01 & -0.99 & 1.00 \\
\hline
\end{tabular}

Degree corresponds to the number of interactions with species in the opposite level. Species strength evaluates the relevance of each species in the network, with higher values for more relevant species. Interaction asymmetry ["species push-pull" in Dormann et al. (2008)] corresponds to the mismatch between a focal species' effect on its interaction partners and the reciprocal effect of the interaction partners on the focal species. Values can range from -1 to 1 (showing highly asymmetric effects either towards opposite level or towards the same species level, respectively). Values equal to 0 depict no interaction asymmetry. Species specificity index evaluates the degree of specificity of each species within the network taking into account the diversity of its interactions. This value reaches 1 when the species is completely specific and 0 when it is absolutely generalist

plant taxa each. The moth that interacted with most plant taxa (13 taxa) was Agrotis ipsilon, however, since more than $50 \%$ of its interactions were with Arbutus unedo, its species specificity index is lower than in the previous species (Table 1B). When it comes to plants, the most specific species was Anacamptis pyramidalis (receiving only visits from Heliothis peltigera). The most generalist species was, by far, Arbutus unedo, which was visited by almost all the moths in our dataset (Table 1A; Fig. 4).

\section{Discussion}

Most moths [except for the Micropterygidae; Heppner (2008)] mainly feed on flower nectar to get energy and do not make use of pollen or manipulate it actively as other pollinators do (e.g. bees and bumblebees). Despite this, moths have been shown to be important pollinators for a wide range of flowering plant species, since pollen attaches to their bodies while feeding and may subsequently be transferred to other flowers (Macgregor et al. 2015). In our study, 20.7\% of our catch had a significant amount of pollen attached to their proboscides. This is a rather low percentage when compared to Banza et al. (2015), who observed that $38 \%$ of their moths had attached more than five pollen grains. In another study, Banza et al. (2019) showed that $27.9 \%$ of their moths across all families transported at least five grains of pollen. Similarly, Walton et al. (2020) found that $23.21 \%$ of their moths carried $\geq 5$ pollen grains, and showed the Noctuidae as dominant pollen-carriers. On the other hand, other pollen transport research has also manifested lower percentages of pollen attached to moths' bodies. Devoto et al. (2011) found that in Scottish pinewoods only 3\% of moths belonging to Noctuidae and Geometridae families carried $\geq 5$ pollen grains in 2007. A year later, this percentage increased up to $10 \%$ in the same location, pollen transport again being dominated by Noctuidae moths. Our results are closer to those observed by Macgregor et al. (2017), who found that $22.2 \%$ of their moths sampled by light traps carried pollen. As mentioned earlier, our research was done specifically on Noctuidae, and with a subset of all catch, so results can only be compared cautiously with those obtained by other studies including other families and bigger sample sizes (Table 2). Plus, studies in different ecosystems (i.e. different vegetation composition) or phenological stages may yield different pollen-transport results. Notwithstanding, across the literature available until now (e.g. Devoto et al. 2011; Hahn and Brühl 2016; Walton et al. 2020), Noctuidae have been shown to be dominant pollen-carriers over other moth families. Therefore, the approach of our research offers a deeper perspective of the ecology of this family. Understanding flower preferences and the role of this family and other nocturnal insects on pollination is paramount to fully understand ecosystem functionality and crucial for conservation of both moths and organisms that might depend on them.

Moths have been reported nectaring on a wide array of plant families such as Adoxaceae (Macgregor et al. 2019), Apiaceae (Macgregor et al. 2017; Walton et al. 2020), Asteraceae (Macgregor et al. 2019; Devoto et al. 2011), Boraginaceae (Banza et al. 2015), Ericaceae (Devoto et al. 2011), Fabaceae (Walton et al. 2020), Lamiaceae (Walton et al. 2020; Macgregor et al. 2017), Malvaceae (Macgregor et al. 2017), Primulaceae (Banza et al. 2015), Rosaceae (Walton et al. 2020; Macgregor et al. 2017, 2019) and 

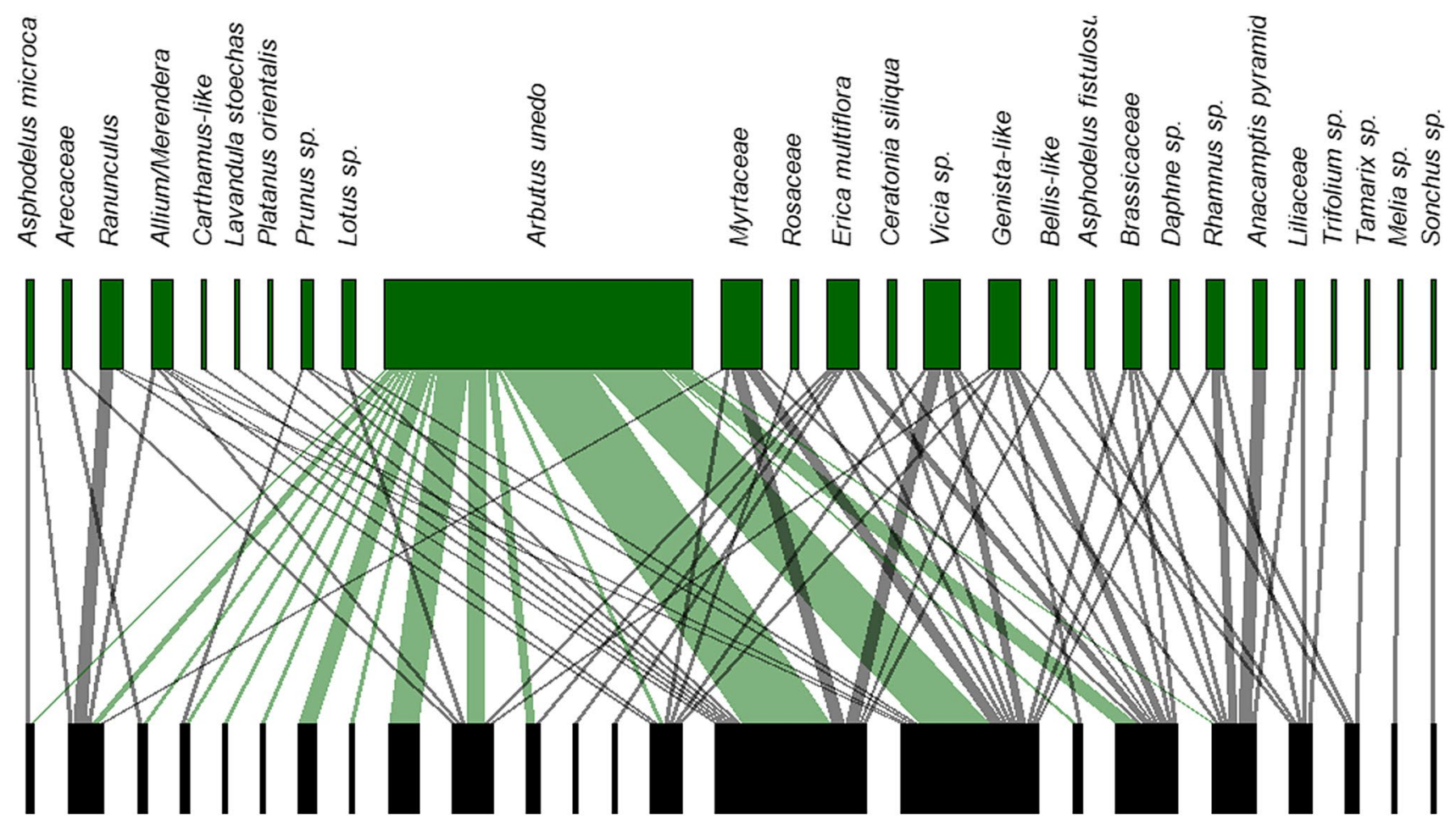

\begin{tabular}{|c|c|c|c|c|c|c|c|c|c|c|}
\hline 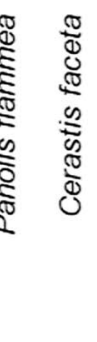 & 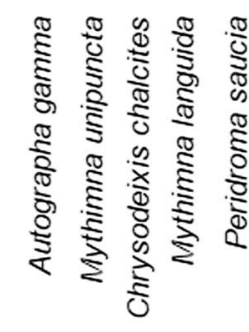 & \multicolumn{2}{|r|}{ 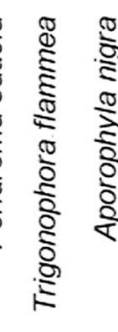 } & 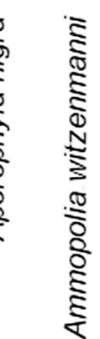 & 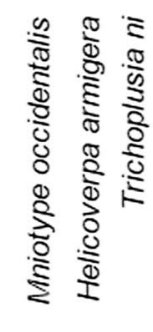 & 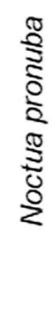 & 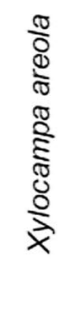 & \multicolumn{2}{|c|}{ 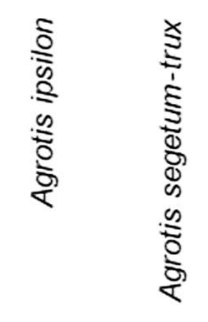 } & $\begin{array}{l}\frac{2}{2} \\
\frac{2}{0} \\
\frac{1}{0} \\
\frac{0}{0} \\
\frac{1}{0} \\
\frac{0}{0}\end{array}$ \\
\hline
\end{tabular}

Fig. 4 Nocturnal pollen-transport network involving all plant (top) and moth (bottom) taxa recorded in this study. The network is weighted so that broader interaction lines represent interactions that were recorded more frequently. Arbutus unedo interactions are highlighted (light green) as the most relevant and generalist species

Table 2 Summary of the metrics calculated at the full network level from pollen-transport networks involving moths in Europe

\begin{tabular}{|c|c|c|c|c|c|}
\hline Metric & This publication & Walton et al. (2020) & Banza et al. (2019) & Banza et al. (2015) & Devoto et al. (2011) \\
\hline Method & Pollen ID & Pollen ID & Pollen ID & Pollen ID & Pollen ID \\
\hline Country & Spain & UK & Portugal & Portugal & UK \\
\hline Pollen $\%$ on moths ( $>5$ grains) & 20.7 & 23.2 & 27.9 & 38 & $3 \%$ in $2007,10 \%$ in 2008 \\
\hline Number of moth species & 23 & 103 & $186^{*}$ & 58 & 25 \\
\hline Number of plant species & 27 & 47 & $52 *$ & 27 & 12 \\
\hline Links per species & 1.68 & 2.040 & $\begin{array}{l}1.04 \text { (moths) } \\
3.00 \text { (plants) }\end{array}$ & 1.64 & 1.21 \\
\hline Linkage density & 5.41 & 12.922 & & 2.38 & \\
\hline $\mathrm{H}_{2}^{\prime}$ & 0.21 & 0.286 & & 0.79 & 0.38 \\
\hline Connectance & 0.11 & 0.063 & & & \\
\hline
\end{tabular}

*Does refer to morphotypes instead of identified species 
Scrophulariaceae (Macgregor et al. 2017, 2019), among others. In the present study, Noctuidae moths interacted with 16 plant families (see Supplementary Material 2). Ericaceae was the most visited family with almost half (46\%) of the moth-plant interactions recorded involving Arbutus unedo. This ericaceous shrub is widely distributed in the Mediterranean Basin and commonly used as a nectar resource by a range of pollinators (Soro and Paxton 1999); importantly, its flowers remain open at night, enabling access by night-flying insects. In our network, all moth species but two visited this plant, which shows the importance of such a floral resource for Noctuidae moths in our study area. Similarly, Devoto et al. (2011) found that Calluna vulgaris (L.) Hull 1808 and Erica cinerea/tetralix were commonly visited by moths at night. Regardless of the similarity between those two species and Erica multiflora, which is very abundant in our sampling area, our results have shown no dominance of this species in the network (i.e. $4.67 \%$ of all the interactions). However, both our results and those from Devoto et al. (2011) underline the importance of the Ericaceae family as a food resource and for the conservation of adult moths within and outside the Noctuidae family. In fact, both generalist and specific moth species in our network interacted with Arbutus unedo (Fig. 4), ultimately giving Arbutus the highest species strength score of the network (i.e. the most relevant species) and the lowest species specificity index (i.e. the most generalist species of the network) (Table 1A). The dominance of Arbutus, visited by almost all moths in our network, makes the moth niche overlap score nearly 0.6 times as high as that of plants, suggesting that plant species tend to hold more specialised interactions than moths. Therefore, the functional role that moth species take in our system is more redundant than that taken by plants, and the loss of one or a few species of pollinators to a perturbation will trigger fewer secondary extinctions at the plant level than the loss of plant species. Moreover, although the average number of links is higher for plants than for moths, plants have a lower and more diverse number of shared partners than moths. This manifests the asymmetry of the network and of its interactions: more specialist plants are pollinated by generalist moths, whilst generalist plants are pollinated by a wide range of both generalist and more specialist moths. Robustness to such loss of species, nevertheless, was similar both at the plant and at the moth level (0.68 and 0.69, respectively). This is supported by the fact that the extinction slope is fairly similar for both moths and plants (2.16 for plants and 2.27 for moths). These values suggest a rather robust network in which functionality will not collapse despite the extinction of a few species (i.e. the function of an extinct species can be assumed by another component of the network). This contrasts with robustness values obtained by Banza et al. (2015) in Portugal, the geographically closest place where pollen-transfer network research involving moths has been conducted. In their study, plants had a lower robustness value than moths, indicating that they were more prone to extinction after the disappearance of moth species than viceversa. Their network, though, was less complex that ours, according to the linkage density metric (Table 2).

Regarding the connection links between the plants and moths in our network, connectance resulted in a value of 0.11 when considering the weight of the network's interactions. This is a rather low value, as was that one found by Walton et al. (2020) in a nocturnal network (see Table 2), or Beltrán and Traveset (2018) when studying bees in the same island. In fact, connectance values are usually low in pollination networks, since only a small number out of the total potential links actually occur (Vizentin-Bugoni et al. 2018). Moreover, this metric is affected by network size and richness, since highly diverse communities usually hold less connected networks because interactions that do not exist between plants and pollinators increase (Beltrán and Traveset 2018; Vizentin-Bugoni et al. 2018).

A network specialisation index $\left(\mathrm{H}_{2}^{\prime}\right)$ of 0.21 suggests that our network is dominated by generalist species. This value is lower (i.e. shows a less specific community) than that found by Banza et al. (2015) when assessing pollen-transportation by moths in Portugal, or that found by Beltrán and Traveset (2018) when studying bees on the same island, albeit it is similar to that found by Walton et al. (2020) and Devoto et al. (2011) (Table 2). Differences in this metric may be due to the fact that we restricted our analyses to a single moth family and used a reduced sample size, whilst others did not; or by the fact that networks built with different methods (e.g. through pollen identification or pollinator visitation census) might show different metric values. Indeed, de Manincor et al. (2020) showed that $\mathrm{H}_{2}^{\prime}$ values were higher in visitbased networks than in pollen-based networks. Moreover, in the case of networks involving bees (e.g. Beltrán and Traveset 2018), we need to keep in mind that pollen is actively collected by them to feed their larvae, and therefore they might have more metabolic restrictions than moths when choosing pollen sources.

Despite most moths and plants being considered generalist in our analyses (Table 1), there were some particular cases in which elements of our network interacted with only one taxon of the opposite level. For instance, the only plant species in our network that did not receive visits from at least two moth species was Anacamptis pyramidalis, which was only visited by Heliothis peltigera [as previously also recorded by Vallius et al. (2013) in Ireland]. However, literature also reports pollinia from this orchid on other Noctuidae such as Cucullia caninae Rambur, 1833 and Tyta luctuosa (Barile et al. 2006; Vallius et al. 2013). Of these, T. luctuosa was recorded in our network, but no pollinia from A. pyramidalis was found attached to its proboscis or elsewhere. Although all moths 
with attached orchid pollinia found in our surveys were included in the network analyses, perhaps a more extensive surveying effort would have yielded more interactions for A. pyramidalis. Similarly, all moth species with more than one recorded interaction visited at least two plant taxa with the exception of Peridroma saucia and Aporophyla nigra, that only visited Arbutus unedo. Nevertheless, A. nigra has also been found carrying pollen of Stachys species in the UK (Walton et al. 2020), a plant that is also present in our study area. Regardless of these interactions appearing specific in the ecological community context from which our network was built, it could be possible for such species to actually not be specific. Furthermore, bigger sample sizes would increase the chances of detecting new interactions. The absence of evidence is not the evidence of absence, and as research on food plants of adult Noctuidae is still scarce and fragmentary, we encourage further research to determine, in-depth, the use of floral resources by moths before jumping to conclusions which species might be specialists when adults.

Moreover, it should be taken into account that flowervisitor networks and effective plant-pollinator interactions are not the same (Pornon et al. 2016). Registering a flower visit (e.g. through pollen on an insect's body) does not necessarily constitute an effective pollination event where pollen from an anther of a particular plant species is successfully transferred to stigmas of female flowers of the same species, ultimately producing seeds (King et al. 2013). We are still far from an extensive knowledge of nocturnal pollination and to what extent night-flying pollinators contribute to plant reproduction. Therefore, there is a need to incorporate functionality measures indicating effective pollination into community studies and pollination networks (Pornon et al. 2016) to effectively assess potential conservation needs for both moths and plant species.

In conclusion, based on the interactions we were able to record, it seems that our nocturnal pollen-transfer network is mostly built by generalist moths and plants, which in turn make such a network robust to perturbations involving species loss. Ericaceous shrubs (and especially Arbutus unedo) proved to be of high importance for the maintenance and conservation of the moth community, scoring as the most relevant plant species. We recommend researching more in-depth the relationship between adult moths (within and outside Noctuidae) and their food plants in the Mediterranean, as it is considered one of the world's richest places in terms of plant and animal diversity (Cuttelod et al. 2009). Moreover, state-of-the-art methodological approaches such as pollen DNA barcoding could be used to increase identification accuracy (Chang et al. 2018; Pornon et al. 2017). Indeed, Macgregor et al. (2019) compared networks built identifying pollen through light microscopy and through
DNA metabarcoding and showed that the latter approach detected more interactions per moth species. Once more interactions between adult moths and their food plants have been unveiled and their role in successful pollination has been assessed, new valuable opportunities for the effective conservation of both plants and moths will emerge.

Supplementary Information The online version contains supplementary material available at https://doi.org/10.1007/s10841-022-00382-7.

Acknowledgements Part of the data in this article was obtained during ERM's MSc thesis at the University of the Balearic Islands, under the guidance of Dr. Samuel Pinya Fernández, who lent her a light trap to conduct fieldwork. We are grateful to the Conselleria de Medi Ambient, Agricultura i Pesca de les Illes Balears for allowing the moth captures under the permits SEN 557/2017 and SEN 303/18. We would also like to thank two anonymous reviewers for their time and insightful comments on this manuscript.

Author contributions ERM and JDC conceived the approach of the present study. ERM conducted fieldwork, moth identification and pollen slide preparation. MB analyzed and identified pollen preparations. JDC conducted statistical analyses and made figures. ERM and JDC wrote the first draft of the manuscript. All authors contributed critically to the drafts and gave final approval for publication.

Funding Open access funding provided by Swedish University of Agricultural Sciences. No other form of funding was received to assist during fieldwork or the preparation of this manuscript.

Code availability The data that support the findings of this study are openly available in: https://github.com/JDiazCalafat/PollenNetwork_ moths_2017-18. To allow a better reproducibility of our results, we recommend the usage of the R package "checkpoint" (Ooi et al. 2021). This allows to install and use the same version of the packages that were available and run at the time of analyzing our data.

\section{Declarations}

Conflict of interest The authors have no competing interests to declare that are relevant to the content of this article.

Open Access This article is licensed under a Creative Commons Attribution 4.0 International License, which permits use, sharing, adaptation, distribution and reproduction in any medium or format, as long as you give appropriate credit to the original author(s) and the source, provide a link to the Creative Commons licence, and indicate if changes were made. The images or other third party material in this article are included in the article's Creative Commons licence, unless indicated otherwise in a credit line to the material. If material is not included in the article's Creative Commons licence and your intended use is not permitted by statutory regulation or exceeds the permitted use, you will need to obtain permission directly from the copyright holder. To view a copy of this licence, visit http://creativecommons.org/licenses/by/4.0/.

\section{References}

Bachelard P (2008) Guide des papillons nocturnes de France: plus de 1620 espèces décrites et illustrées. Delachaux et Niestlé 
Banza P, Belo AD, Evans DM (2015) The structure and robustness of nocturnal Lepidopteran pollen-transfer networks in a Biodiversity Hotspot. Insect Conserv Divers 8(6):538-546

Banza P, Macgregor CJ, Belo AD, Fox R, Pocock MJ, Evans DM (2019) Wildfire alters the structure and seasonal dynamics of nocturnal pollen-transport networks. Funct Ecol 33(10):1882-1892

Barile MC, Cozzolino S, De Castro O, Lucchese F, Zilli A (2006) New insights into pollination of Mediterranean terrestrial orchids by butterflies and moths. J Eur Orch 38:449-460

Bell JR, Botham MS, Henrys PA, Leech DI, Pearce-Higgins JW, Shortall CR, Brereton TM, Pickup J, Thackeray SJ (2019) Spatial and habitat variation in aphid, butterfly, moth and bird phenologies over the last half century. Glob Change Biol 25(6):1982-1994

Beltrán R, Traveset A (2018) Redes de interacción entre flores e himenópteros en dos comunidades costeras. Efectos de la pérdida de hábitat. Ecosistemas 27(2):102-114

Betzholtz PE, Franzen M (2011) Mobility is related to species traits in noctuid moths. Ecol Entomol 36(3):369-376

Biesmeijer JC, Roberts SP, Reemer M, Ohlemüller R, Edwards M, Peeters T, Schaffers AP, Potts SG, Kleukers R, Thomas CD, Settele J, Kunin WE (2006) Parallel declines in pollinators and insect-pollinated plants in Britain and the Netherlands. Science 313(5785):351-354

Bumrungsri S, Harbit A, Benzie C, Carmouche K, Sridith K, Racey P (2008) The pollination ecology of two species of Parkia (Mimosaceae) in southern Thailand. J Trop Ecol 24(5):467-475

Chang H, Guo J, Fu X, Liu Y, Wyckhuys KA, Hou Y, Wu K (2018) Molecular-assisted pollen grain analysis reveals spatiotemporal origin of long-distance migrants of a noctuid moth. Int J Mol Sci 19(2):567

Cordeiro GD, Pinheiro M, Dötterl S, Alves-dos-Santos I (2017) Pollination of Campomanesia phaea (Myrtaceae) by night-active bees: a new nocturnal pollination system mediated by floral scent. Plant Biol 19(2):132-139

Cuttelod A, García N, Malak DA, Temple HJ, Katariya V (2009) The Mediterranean: a biodiversity hotspot under threat. Wildlife in a changing world - an analysis of the 2008 IUCN red list of threatened species. IUCN, Gland

Davies H, Butler CA (2008) Do butterflies bite?: Fascinating answers to questions about butterflies and moths. Rutgers University Press, New Brunswick

de Manincor N, Hautekèete N, Mazoyer C, Moreau P, Piquot Y, Schatz B, Schmitt E, Zélazny M, Massol F (2020) How biased is our perception of plant-pollinator networks? A comparison of visit-and pollen-based representations of the same networks. Acta Oecologica 105:103551

Devoto M, Bailey S, Memmott J (2011) The 'night shift': nocturnal pollen-transport networks in a boreal pine forest. Ecol Entomo 36(1):25-35

Dormann CF (2011) How to be a specialist? Quantifying specialisation in pollination networks. Netw Biol 1:1-20

Dormann CF, Gruber B, Fruend J (2008) Introducing the bipartite package: analysing ecological networks. R News 8(2):8-11

Dormann CF, Fruend J, Bluethgen N, Gruber B (2009) Indices, graphs and null models: analyzing bipartite ecological networks. Open Ecol J 2:7-24

Garau GA, Gelabert MG (2009) Tormentas y precipitaciones estivales en Mallorca. Microcontinentalidad y brisas marinas. Geografía, territorio y paisaje. El estado de la cuestión: actas del XXI Congreso de Geógrafos Españoles. Ciudad Real, 27-29 de octubre de 2009. Universidad de Castilla-La Mancha, Ciudad Real, pp $1681-1690$

Gill RJ, Baldock KC, Brown MJ, Cresswell JE, Dicks LV, Fountain MT, Garratt MPD, Gough LA, Heard MS, Holland JM, Ollerton J, Stone GN, Tang CQ, Vanbergen AJ, Vogler AP, Woodward G, Arce AN, Boatman ND, Brand-Hardy R, Breeze TD, Green M,
Hartfield CM, O'Connor RS, Osborne JL, Phillips J, Sutton PB, Potts SG (2016) Protecting an ecosystem service: approaches to understanding and mitigating threats to wild insect pollinators. Advances in ecological research, vol 54. Academic Press, Cambridge, pp 135-206

González-Varo JP, Biesmeijer JC, Bommarco R, Potts SG, Schweiger O, Smith HG, Steffan-Dewenter I, Szentgyörgyi H, Woyciechowski M, Vilà M (2013) Combined effects of global change pressures on animal-mediated pollination. Trends Ecol Evol 28(9):524-530

Hahn M, Brühl CA (2016) The secret pollinators: an overview of moth pollination with a focus on Europe and North America. Arthropod-Plant Interact 10(1):21-28

Heppner JB (2008) Mandibulate archaic moths (Lepidoptera: Micropterigidae). In: Capinera JL (ed) Encyclopedia of entomology. Springer, Dordrecht, pp 2281-2281. https://doi.org/10.1007/ 978-1-4020-6359-6_1702

Herrera CM (1987) Components of pollinator "quality": comparative analysis of a diverse insect assemblage. Oikos 79-90

Hesse M, Halbritter H, Zetter R, Weber M, Buchner R, Frosch-Radivo A, Ulrich S (2009) Pollen terminology: an illustrated handbook. Springer Science \& Business Media, New York, Wien

Jonason D, Franzen M, Ranius T (2014) Surveying moths using light traps: effects of weather and time of year. PloS one 9(3):e92453

King C, Ballantyne G, Willmer PG (2013) Why flower visitation is a poor proxy for pollination: measuring single-visit pollen deposition, with implications for pollination networks and conservation. Methods Ecol Evol 4(9):811-818

Krenn HW (1990) Functional morphology and movements of the proboscis of Lepidoptera (Insecta). Zoomorphology 110(2):105-114

Krenn HW (2010) Feeding mechanisms of adult Lepidoptera: structure, function, and evolution of the mouthparts. Annu Rev Entomol 55:307-327

Kristensen NP, Scoble MJ, Karsholt O (2007) Lepidoptera phylogeny and systematics: the state of inventorying moth and butterfly diversity. Zootaxa 1668(1):699-747

Leiva CL, Moris MO (2001) Identificación y cartografía de tipos estructurales y niveles de madurez en la vegetación de la Isla de Mallorca. In Congresos Forestales

Macgregor CJ, Scott-Brown AS (2020) Nocturnal pollination: an overlooked ecosystem service vulnerable to environmental change. Emerg Topics Life Sci 4(1):19-32

Macgregor CJ, Pocock MJ, Fox R, Evans DM (2015) Pollination by nocturnal Lepidoptera, and the effects of light pollution: a review. Ecol Entomol 40(3):187-198

Macgregor CJ, Evans DM, Fox R, Pocock MJ (2017) The dark side of street lighting: impacts on moths and evidence for the disruption of nocturnal pollen transport. Glob Change Biol 23(2):697-707

Macgregor CJ, Kitson JJ, Fox R, Hahn C, Lunt DH, Pocock MJ, Evans DM (2019) Construction, validation, and application of nocturnal pollen transport networks in an agro-ecosystem: a comparison using light microscopy and DNA metabarcoding. Ecol Entomol 44(1):17-29

Mitter C, Poole RW, Matthews M (1993) Biosystematics of the heliothinae (Lepidoptera: Noctuidae). Annu Rev Entomol 38(1):207-225

Ollerton J, Winfree R, Tarrant S (2011) How many flowering plants are pollinated by animals? Oikos 120(3):321-326

Ooi H, de Vries A, Microsoft (2021) Checkpoint: install packages from snapshots on the checkpoint server for reproducibility. R package version 1.0.0. Available at https://CRAN.R-project.org/package= checkpoint

Orford KA, Vaughan IP, Memmott J (2015) The forgotten flies: the importance of non-syrphid Diptera as pollinators. Proc R Soc B Biol Sci 282(1805):20142934

Pornon A, Escaravage N, Burrus M, Holota H, Khimoun A, Mariette J, Pellizzari C, Iribar A, Etienne R, Taberlet P, Vidal M, Winterton 
P, Zinger L, Andalo C (2016) Using metabarcoding to reveal and quantify plant-pollinator interactions. Sci Rep 6(1):1-12

Pornon A, Andalo C, Burrus M, Escaravage N (2017) DNA metabarcoding data unveils invisible pollination networks. Sci Rep $7(1): 1-11$

Potts SG, Biesmeijer JC, Kremen C, Neumann P, Schweiger O, Kunin WE (2010) Global pollinator declines: trends, impacts and drivers. Trends Ecol Evol 25(6):345-353

R Core Team (2021) R: a language and environment for statistical computing. R Foundation for Statistical Computing, Vienna

Rader R, Bartomeus I, Garibaldi LA, Garratt MP, Howlett BG, Winfree R, Cunningham SA, Mayfield MM, Arthur AD, Andersson GKS, Bommarco R, Brittain C, Carvalheiro LG, Chacoff NP, Entling MH, Foully B, Freitas BM, Gemmill-Herren B, Ghazoul J, Griffin SR, Gross CL, Herbertsson L, Herzog F, Hipólito J, Jaggar S, Jauker F, Klein A, Kleijn D, Krishnan S, Lemos CQ, Lindström SAM, Mandelik Y, Monteiro VM, Nelson W, Nilsson L, Pattemore DE, Pereira NO, Pisanty G, Potts SG, Reemer M, Rundlöf M, Sheffield CS, Scheper J, Schüepp S, Smith HG, Stanley DA, Stout JC, Szentgyörgyi H, Taki H, Vergara CH, Viana BF, Woyciechowski M (2016) Non-bee insects are important contributors to global crop pollination. Proc Natl Acad Sci 113(1):146-151

Reille M (1992) Pollen et spores d'Europe et d'Afrique du Nord. Lab. Bot. Hist. \& Palynol. URA CNRS/Univ. Marseille III, Marseille

Reille M (1995) Pollen et spores d'Europe et d'Afrique du Nord. Additional issue 1. Laboratoire de Botanique Historique et Palynologie, Marseille

Reille M (1998) Pollen et spores d'Europe et d'Afrique du Nord. Additional issue 2. Laboratoire de Botanique Historique et Palynologie, Marseille

Regier JC, Zwick A, Cummings MP, Kawahara AY, Cho S, Weller S, Roe A, Baixeras J, Brown JW, Parr C, Davis DR, Epstein M, Hallwachs W, Hausmann A, Janzen DH, Kitching IJ, Solis M, Yen S-H, Bazinet AL, Mitter C (2009) Toward reconstructing the evolution of advanced moths and butterflies (Lepidoptera: Ditrysia): an initial molecular study. BMC Evol Biol 9(1):1-21

Richardson RT, Lin CH, Quijia JO, Riusech NS, Goodell K, Johnson RM (2015) Rank-based characterization of pollen assemblages collected by honey bees using a multi-locus metabarcoding approach. Appl Plant Sci 3(11): 1500043

Ricketts TH, Daily GC, Ehrlich PR, Fay JP (2001) Countryside biogeography of moths in a fragmented landscape: biodiversity in native and agricultural habitats. Conserv Biol 15(2):378-388
Siquier I Vigrós JL, Salom JC (2003) Contribució al coneixement micològic de les Illes Balears X: el Parc Natural de Mondragó (Santanyí, Mallorca). Rev Catal Micol 25:31-40

Soldevilla CG, González PC, Teno PA, Vilches ED (2007) Spanish Aerobiology Network (REA): management and quality manual. Publicaciones de La Universidad de Córdoba, Córdoba, pp 1-300

Soro A, Paxton RJ (1999) The strawberry tree: a significant source of nectar around the Mediterranean basin. Bee World 80(3):140-144

Valdés B, Diez MJ, Fernandez I (1987) Atlas polinico de Andalucia occidental. Instituto de Desarrollo Regional, Universidad de Sevilla, Excma. Diputacion de Cadiz, Sevilla

Vallius E, Buchsbaum U, Nazarov V (2013) Pollination activity of Zygaena filipendulae (Linnaeus, 1758) (Lepidoptera: Zygaenidae) in Anacamptis pyramidalis orchid on the north Bull Island (Ireland). Entomofauna 34:357-368

Van Zandt PA, Johnson DD, Hartley C, LeCroy KA, Shew HW, Davis BT, Lehnert MS (2020) Which moths might be pollinators? Approaches in the search for the flower-visiting needles in the Lepidopteran haystack. Ecol Entomol 45:13-25

Vázquez DP, Melián CJ, Williams NM, Blüthgen N, Krasnov BR, Poulin R (2007) Species abundance and asymmetric interaction strength in ecological networks. Oikos 116(7):1120-1127

Vizentin-Bugoni J, Maruyama PK, de Souza CS, Ollerton J, Rech AR, Sazima M (2018) Plant-pollinator networks in the tropics: a review. Ecological networks in the tropics. Springer, Cham, pp 73-91

Walton RE, Sayer CD, Bennion H, Axmacher JC (2020) Nocturnal pollinators strongly contribute to pollen transport of wild flowers in an agricultural landscape. Biol Lett 16(5):20190877

Waring P, Townsend M (2017) Field guide to the moths of Great Britain and Ireland. Bloomsbury Publishing

Willmer P (2011) Pollination by butterflies and moths. In: Pollination and floral ecology. Princeton University Press, pp 322-336

Winfree R, Bartomeus I, Cariveau DP (2011) Native pollinators in anthropogenic habitats. Annu Rev Ecol Evol Syst 42:1-22

Publisher's Note Springer Nature remains neutral with regard to jurisdictional claims in published maps and institutional affiliations. 